\title{
Safeguarding maternal and child health in South Africa by starting the Child Support Grant before birth: Design lessons from pregnancy support programmes in 27 countries
}

\author{
M F Chersich, ${ }^{1,2}$ MB BCh, PhD; S Luchters, ${ }^{3,4,5}$ MB BCh, MSc (Public Health), PhD; D Blaauw, ${ }^{1}$ MB BCh, FCPHM (SA); \\ F Scorgie, ${ }^{2}$ MA, PhD; E Kern, ${ }^{1}$ BA Hons, Dip Information Science; A van den Heever, ${ }^{6}$ MA (Economics); H Rees, ${ }^{2}$ MB BChir, MA, MRCGP; \\ E Peach, ${ }^{3}$ BMBS, MPH, MSES; S Kharadi, ${ }^{7}$ BSc Hons; S Fonn, ${ }^{8} \mathrm{MB}$ BCh, PhD \\ ${ }^{1}$ Centre for Health Policy, School of Public Health, Faculty of Health Sciences, University of the Witwatersrand, Johannesburg, South Africa \\ ${ }^{2}$ Wits Reproductive Health and HIV Institute, Faculty of Health Sciences, University of the Witwatersrand, Johannesburg, South Africa \\ ${ }^{3}$ Burnet Institute, Melbourne, Australia \\ ${ }^{4}$ Department of Epidemiology and Preventive Medicine, Medicine, Nursing and Health Sciences, Monash University, Australia \\ ${ }^{5}$ International Centre for Reproductive Health, Department of Urogynaecology, Faculty of Medicine and Health Sciences, Ghent University, \\ Belgium \\ ${ }^{6}$ Wits School of Governance, Faculty of Commerce, Law and Management, University of the Witwatersrand, Johannesburg, South Africa \\ Independent consultant, Toronto, Canada \\ ${ }^{8}$ Gender and Health Unit, School of Public Health, Faculty of Health Sciences, University of the Witwatersrand, Johannesburg, South Africa
}

Corresponding author: M Chersich (mchersich@wrhi.ac.za)

\begin{abstract}
Background. Deprivation during pregnancy and the neonatal period increases maternal morbidity, reduces birth weight and impairs child development, with lifelong consequences. Many poor countries provide grants to mitigate the impact of poverty during pregnancy. South Africa (SA) offers a post-delivery Child Support Grant (CSG), which could encompass support during pregnancy, informed by lessons learnt from similar grants.

Objectives. To review design and operational features of pregnancy support programmes, highlighting features that promote their effectiveness and efficiency, and implications thereof for SA.

Methods. Systematic review of programmes providing cash or other support during pregnancy in low- and middle-income countries. Results. Thirty-two programmes were identified, across 27 countries. Programmes aimed to influence health service utilisation, but also longer-term health and social outcomes. Half included conditionalities around service utilisation. Multifaceted support, such as cash and vouchers, necessitated complex parallel administrative procedures. Five included design features to diminish perverse incentives. These and other complex features were often abandoned over time. Operational barriers and administrative costs were lowest in programmes with simplified procedures and that were integrated within child support.

Conclusions. Pregnancy support in SA would be feasible and effective if integrated within existing social support programmes and operationally simple. This requires uncomplicated enrolment procedures (e.g. an antenatal card), cash-only support, and few or no conditionalities. To overcome political barriers to implementation, the design might initially need to include features that discourage pregnancy incentives. Support could incentivise service utilisation, without difficult-to-measure conditionalities. Beginning the CSG in pregnancy would be operationally simple and could substantially transform maternal and child health.
\end{abstract}

S Afr Med J 2016;106(12):1192-1210. DOI:10.7196/SAMJ.2016.v106i12.12011

Income poverty and inequality remain pervasive worldwide, leaving many households with insufficient resources to meet their needs. In South Africa (SA), one of the most inequitable countries in the world, the poorest $20 \%$ of the population consumes only $4 \%$ of the country's goods and services, while the richest $20 \%$ takes $61 \% .{ }^{[1]}$ Pregnancy and childbearing further marginalise vulnerable women and children by reducing income-generating potential and introducing a host of new financial needs. Only $14 \%$ of pregnant women in the poorest quartile are employed, either in the informal or the formal sector. ${ }^{[2]}$

Pregnancy and breastfeeding considerably increase the volume and variety of food a women needs. ${ }^{[3]}$ Inadequate nutrition during pregnancy results in adverse birth outcomes, suboptimal neonatal growth and development, and impaired cognitive development later in life. ${ }^{[4]}$ Essentially, the nutritional status of the fetus in utero has a marked effect on subsequent child health and life chances, as well as intergenerational effects. ${ }^{[5]}$ Also, during pregnancy women incur substantial costs for accessing services, such as transport and childcare for existing children, while seeking healthcare.

A large number of countries, including SA, have recognised the importance of providing support for children living in impoverished households, and the extent and range of benefits accrued are well documented. ${ }^{[6]}$ The SA Child Support Grant (CSG), which began in 1998, provides ZAR350 (USD26) per month for children from birth up to 18 years. Eligibility is based on a means test, and currently there are over 10 million beneficiaries. ${ }^{[6]}$ Timing this support to begin only once a child is born, however, limits its effectiveness and cannot undo the harms of maternal deprivation during pregnancy. Conversely, providing support to women during pregnancy would enable an improvement in maternal nutrition and overall wellbeing. The earlier in pregnancy such support begins, the more optimal placental 
transfer of nutrients will be, with benefits both for the child and for subsequent generations. ${ }^{[7]}$

There is compelling empirical evidence that pregnancy support programmes alleviate the vulnerability of pregnant women - and, by extension, of their fetuses - with consequent improvements in maternal and child health outcomes. ${ }^{[8]}$ Randomised trials in Latin America and South-East Asia have demonstrated that pregnancy grants can promote weight gain during pregnancy, reduce maternal anaemia, raise antenatal care (ANC) and skilled birth attendant (SBA) coverage, reduce maternal mortality, and prevent low-birthweight births and infant mortality, among other benefits (see Table 1). Similarly, several SA studies have shown that among child beneficiaries of the CSG, the largest gains from this form of support come in the very early nutrition window of childhood. In one modelling study, children who began receiving the CSG within the first year of life had a 0.45 higher height-for-age $z$-score than other children, and this was expected to translate into an average $5-7 \%$ higher monthly wage as adults. ${ }^{[9]}$

The effect of extending the existing social welfare system in SA to encompass pregnant women would depend on how well it is designed and implemented. Identifying lessons from experiences with pregnancy support programmes in other low- and middle-income countries (LMICs) could help inform the design of and optimise gains from a similar programme in SA, and indicate how best to build

\begin{tabular}{|c|c|c|}
\hline Benefit category & Type of benefit & Description of impact \\
\hline $\begin{array}{l}\text { Maternal } \\
\text { nutrition }\end{array}$ & $\begin{array}{l}\text { Maternal weight gain and } \\
\text { anaemia }\end{array}$ & $\begin{array}{l}\text { More women gain weight necessary for healthy pregnancy, but also some rise in } \\
\text { maternal obesity noted in two studies. }{ }^{[10]} \text { Reduced maternal anaemia. Improved } \\
\text { maternal nutrition can lower maternal anaemia by } 39 \% .^{[10,11]}\end{array}$ \\
\hline Gender relations & $\begin{array}{l}\text { Women's position within } \\
\text { household }\end{array}$ & $\begin{array}{l}\text { Increases in women's bargaining power and intra-household decision-making, and } \\
\text { reduced domestic violence. Long-term support increased marriage rates by } 4 \% .{ }^{[12]}\end{array}$ \\
\hline Equity & Targeting and impact on poor & $\begin{array}{l}\text { Successfully targeted poor in most instances. Impacts generally greater in poor than } \\
\text { other groups. }\end{array}$ \\
\hline \multirow[t]{2}{*}{$\begin{array}{l}\text { Health service } \\
\text { utilisation }\end{array}$} & ANC attendance & $\begin{array}{l}\text { Rise in ANC attendance in eight studies, ranging from } 19 \% \text { in a trial in Honduras }{ }^{[13]} \text { to } \\
65 \% \text { in Peru }{ }^{[14]} \text { and a } 4 \text {-fold increase in Bolivia. }{ }^{[15]}\end{array}$ \\
\hline & SBA coverage & $\begin{array}{l}\text { Rose } 3.6 \text {-fold in Bangladesh }{ }^{[16]} \text { and rose in four other countries. Also improved } \\
\text { timeliness of access to services in childbirth. }\end{array}$ \\
\hline $\begin{array}{l}\text { Health services } \\
\text { quality }\end{array}$ & Quality of care & $\begin{array}{l}\text { Low-quality health services limit the benefits gained by higher patient demand for } \\
\text { services. However, more empowered, informed and proactive patients demanded } \\
\text { higher-quality services, thus improving service quality. }\end{array}$ \\
\hline \multirow{9}{*}{$\begin{array}{l}\text { Maternal health } \\
\text { and wellbeing } \\
\text { Child health }\end{array}$} & Maternal mortality & Grant reduced maternal mortality by $11 \%$ in Mexico, ${ }^{[17]}$ but voucher scheme did not. ${ }^{[18]}$ \\
\hline & Physical and mental stress & Women more able to rest in late pregnancy, with reduced physical and mental stress. \\
\hline & Stillbirth rate & Improved nutrition can reduce stillbirths by $45 \%{ }^{[19]}$ \\
\hline & Birth weight & $\begin{array}{l}\text { Mexico trial showed } 127 \mathrm{~g} \text { rise in birth weight from the grant. }{ }^{[20]} \text { Reduction in low birth } \\
\text { weight }(<2500 \mathrm{~g}) \text { varied from } 5 \% \text { in Mexico }{ }^{[20]} \text { to } 15 \% \text { in Uruguay, }{ }^{[21]} 0-30 \% \text { in the } \\
\text { USA and } 40 \% \text { in black recipients in the USA. }{ }^{[22]} \text { In Columbia, newborn weight rose in } \\
\text { urban but not rural areas. Improved nutrition during pregnancy can reduce low birth } \\
\text { weight by } 16 \% \cdot{ }^{[23]}\end{array}$ \\
\hline & $\begin{array}{l}\text { Premature and small-for- } \\
\text { gestational-age babies }\end{array}$ & $\begin{array}{l}\text { No effects on prematurity in Uruguay, but marked reductions in the USA. Also, with } \\
\text { each } 10 \% \text { increase in duration of support in the USA, the risk of a full-term small-for- } \\
\text { gestational-age baby dropped by } 2.5 \% \cdot{ }^{[7]} \text { Improved nutrition in pregnancy can reduce } \\
\text { the prevalence of small-for-gestational-age babies by } 14-32 \% \cdot{ }^{[23]}\end{array}$ \\
\hline & Infant growth & $\begin{array}{l}\text { Infants in the intervention arm of the Mexico trial were } 1.1 \mathrm{~cm} \text { taller and had less } \\
\text { childhood anaemia. }{ }^{[24]} \text { In the USA, infants of grant recipients were much more likely to } \\
\text { be of normal weight and length, and 2-fold more likely to be perceived as having good } \\
\text { health, than non-recipients. }{ }^{25]}\end{array}$ \\
\hline & Newborn and infant survival & $\begin{array}{l}\text { USA grantees had a lower infant mortality rate, and infant mortality was } 11 \% \text { lower in } \\
\text { Mexico. In India a grant lowered perinatal deaths by } 3.7 / 1000 \text { and neonatal deaths by } \\
2.3 / 1000 .{ }^{[26]} \text { Improved maternal nutrition can reduce neonatal mortality by } 38 \% \text { and } \\
\text { infant mortality by } 22 \% .{ }^{[23]}\end{array}$ \\
\hline & Child growth and development & $\begin{array}{l}\text { Offspring of women receiving a grant in Mexico had higher height at } 24 \text { - } 68 \text { months, } \\
\text { fewer were stunted and fewer were overweight. }{ }^{\left[{ }^{10]}\right.} \text { Grants increased childhood motor and } \\
\text { cognitive development, and receptive language abilities. }{ }^{[27]} \text { In Brazil, children from families } \\
\text { who received a grant were } 26 \% \text { more likely to be of normal height and weight. }{ }^{[28]} \text { In SA, } \\
\text { children beginning the CSG in infancy had a } 0.45 \text { higher height-for-age } z \text {-score than } \\
\text { other children. } .^{[9]}\end{array}$ \\
\hline & $\begin{array}{l}\text { Human capital and long-term } \\
\text { development }\end{array}$ & $\begin{array}{l}\text { SA research shows that height at } 2 \text { years is the best predictor of human capital, and } \\
\text { that damage suffered in early life leads to permanent impairment and affects future } \\
\text { generations. }{ }^{[4]} \text { Improving child nutrition during infancy and before } 3 \text { years can raise } \\
\text { adult income by } 46 \% \text { in men. } .^{[29]}\end{array}$ \\
\hline
\end{tabular}


upon existing social support programmes. We conducted a systematic review of pregnancy support programmes in LMICs, examining their objectives, types of support provided and factors facilitating implementation, and then considered the implications of these findings for providing an integrated SA maternal and child support programme starting in pregnancy. The health and social impacts of pregnancy support were not reviewed in detail, as these have already been clearly demonstrated in multiple systematic reviews (Table 1).

\section{Methods}

The systematic review began with a scoping search of Medline (PubMed) using subject headings and thesaurus terms. The full search strategy and terms are provided in Appendix 1. In brief, electronic databases including Academic Search Complete, Psychology and Behavioural Sciences Collection, Educational Resources Information Centre and Global Health Library were searched in August 2012. Reference lists of included articles were examined to identify other eligible articles. We also searched the websites of relevant international organisations (the World Bank, Save the Children and the United Nations Development Programme) for additional 'grey literature' (print and electronic format documents that are not produced by commercial publishers).

To be included in the review, documents had to describe projects implemented in a LMIC that provided cash or vouchers (redeemable for services or commodities) for women or the households in which they lived during pregnancy or childbirth. Projects that only provided postpartum support were excluded. Cash or other support during pregnancy could be the only intervention, or form part of a suite of interventions. We included both state and non-governmental programmes, operational at a national or local level. Excluded were projects that: $(i)$ had pro-natalist objectives (i.e. aimed specifically to increase fertility in the target population); (ii) provided occupational benefits as part of paid maternity leave for women in the formal sector; (iii) entailed only user-fee exemptions at health facilities for pregnant women; and (iv) provided support other than cash or vouchers, such as only nutritional supplements.

A single reviewer extracted data on: (i) the groups targeted and objectives of support; (ii) key design features, including the means of identifying target groups, the type and duration of support, and conditionalities; and (iii) practical experiences with implementation, including administrative challenges faced with eligibility screening, disbursement or verification of conditionalities being met. The outcomes and impact of pregnancy support were also extracted, but are only summarised here (Table 1) as they have been reviewed extensively elsewhere. ${ }^{[8]}$

The analysis focused on comparing the objectives and design of projects across settings and identifying the challenges encountered by projects with different design formats and implementation strategies. We also assessed programme changes over time, and what lessons could be derived from these changes. Finally, we discussed the implications of the overall findings for the SA social grant system.

\section{Results}

The search identified 5822 documents, from which we located a total of 32 programmes across 27 countries (Table 2). Data were drawn from 57 articles eligible for the review. Only four had started before 2000 , with a median onset of 2005. Eight were in sub-Saharan Africa.

\section{Target groups and support objectives}

Two main categories of support could be differentiated. The first targeted only pregnant women $(n=12)$. These initiatives were mainly found in South-East Asia (8/12), and primarily aimed to increase utilisation of public sector ANC, SBAs and postpartum care among poor women. Generally, the schemes did not specifically aim to encourage early ANC attendance, although in the Indira Gandhi Matriva Sahyog Yojana (IGMSY) (Table 2, row 5) women had to register their pregnancy before 4 months' gestation to be eligible, and this indirectly incentivised early booking. In some of these programmes assistance was also framed more broadly as a strategy for improving the health and nutrition of pregnant and lactating mothers, for example to enable adequate rest during pregnancy and after delivery (India, row 3), and to encourage optimal infant feeding practices. Finally, a few programmes, mainly in India, conceptualised maternity support as a means of compensating women for their reduced income-earning potential during pregnancy. The Dr Muthulakshmi Maternity Assistance Scheme (DMMAS) programme in India, for example, specifically seeks to 'assist poor women with medical expenses around childbirth and compensate them for loss of wages around this time' (row 3).

The second group of programmes $(n=20)$ targeted pregnant women among other groups, such as children and vulnerable families or households. Most of these programmes were located in Latin America and the Caribbean (12/20), and framed their objectives in much broader terms than the first category. Many were targeted primarily at reducing poverty and food insecurity, or the building of social equity or solidarity, rather than health per se. For some, the focus was mainly on addressing childhood poverty, as in Peru (row 30), where programmes aimed to use pregnancy support as a way to create improved social safety nets for children. In addition, several schemes had more long-term aspirations, such as breaking intergenerational poverty cycles (Brazil, row 15; El Salvador, row 16; Peru, row 30; Mexico, row 25), making investments in human capital (Brazil, row 15; Peru, row 30; Jamaica, row 24; Ethiopia, rows 17 and 18), or building social capital (Paraguay, row 29) and inclusivity (Panama, row 28).

\section{Identifying target groups}

Programmes adopted one of two strategies for selecting recipients, either targeting all women in selected poor areas, districts or states, or identifying individual poor women, regardless of where they lived. Two-stage processes were sometimes used, where municipal or district areas were selected first, followed by the identification of vulnerable households (Peru, row 30). Methods used to identify individuals varied widely, including the use of a short interview (India, row 3, Cambodia, row 2); tasking ANC staff with identifying eligible recipients, such as women with anaemia or slow weight gain during pregnancy; and home visits to estimate socioeconomic status, based on the characteristics of households. Countries that opted to target all women in an area cited the costs of screening as the rationale for their choice (Bangladesh, row 1; Nepal, row 8).

Several maternity grants were specifically configured to counter the concerns of politicians and popular opinion that a grant would incentivise pregnancy (especially among young women), or even discourage women from accessing abortion services. Features of such grants included restricting eligibility to a certain number of children (India, rows 4 and 5; Nepal, row 8), to women aged $>19$ years (India, rows 4 and 5) and to those with birth spacing of $>2$ years (Bangladesh, row 1), and providing a fixed fee per household rather than payments per child, thereby favouring small families (El Salvador, row 16). Others included a condition that recipients attend family planning services for 2 years after childbirth, or incorporated attending talks on contraception as conditionalities. 


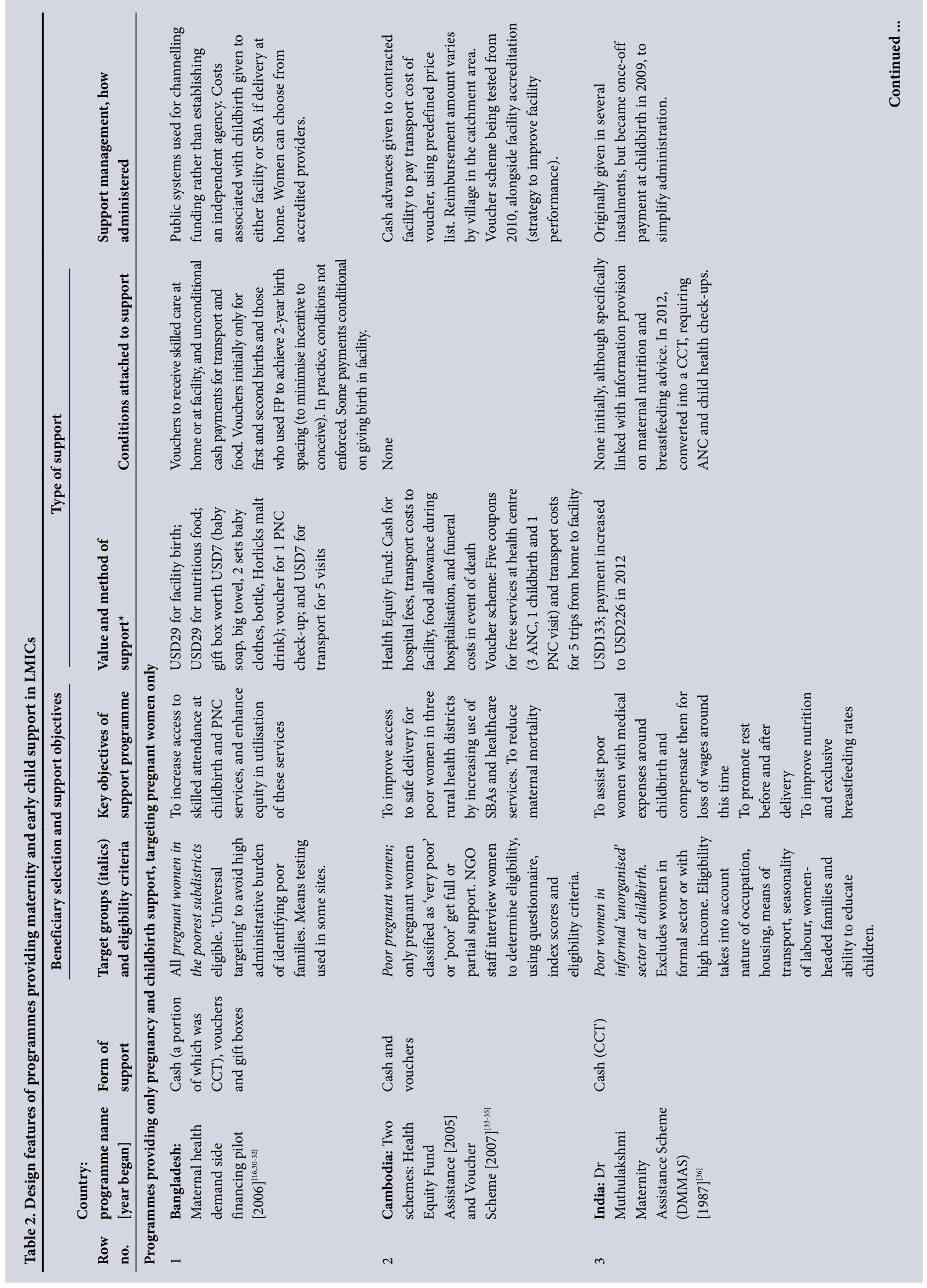




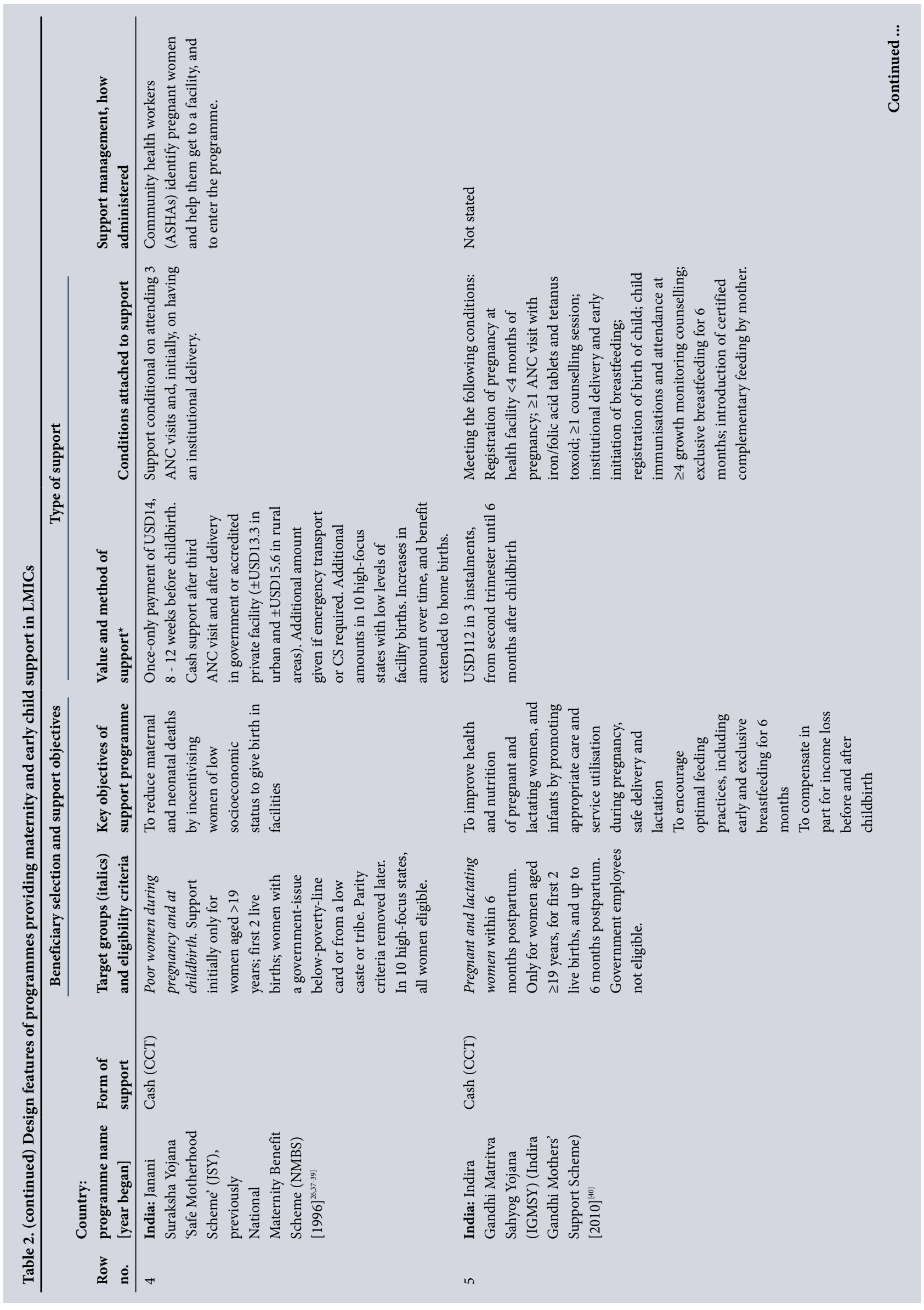




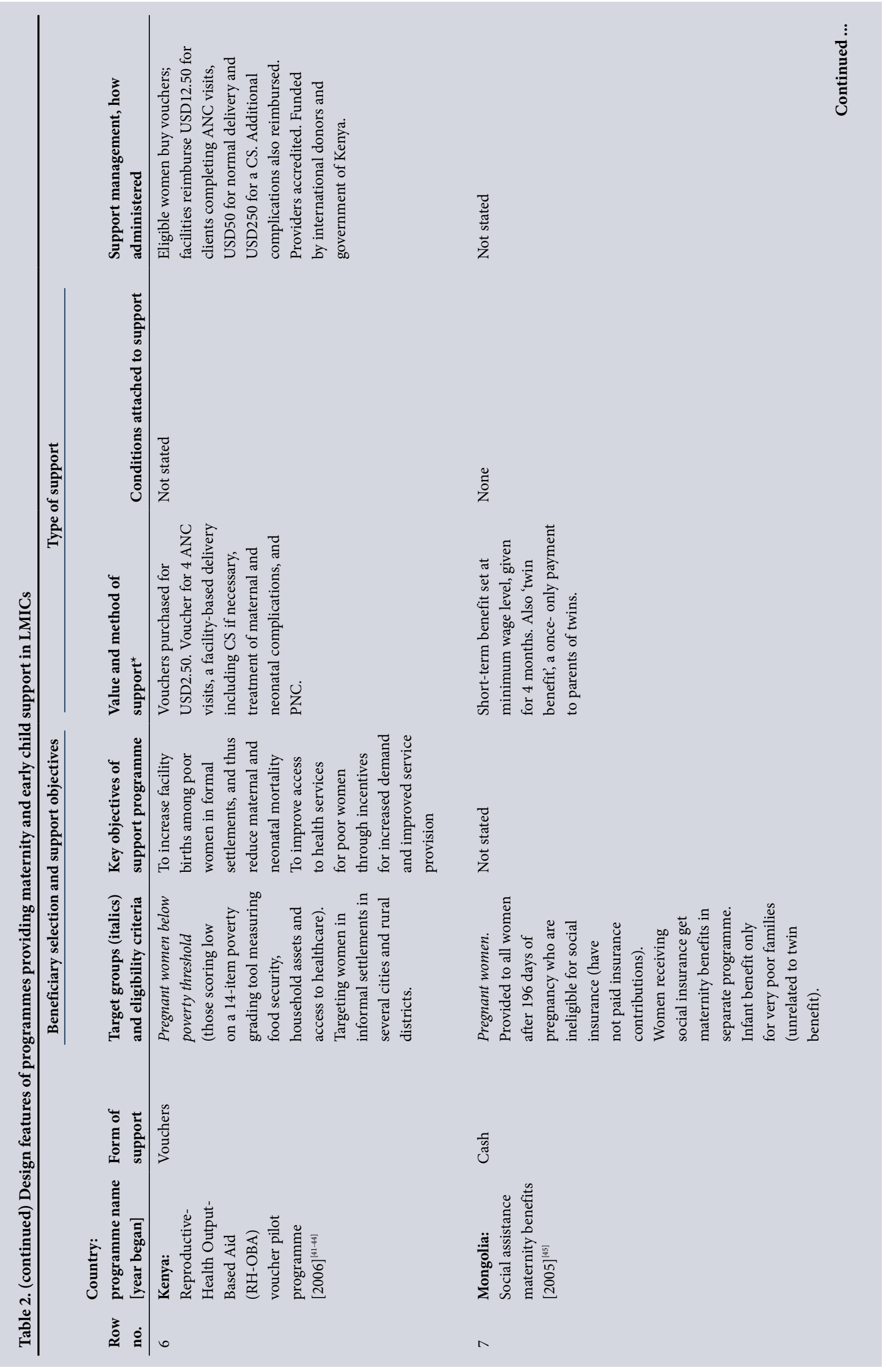




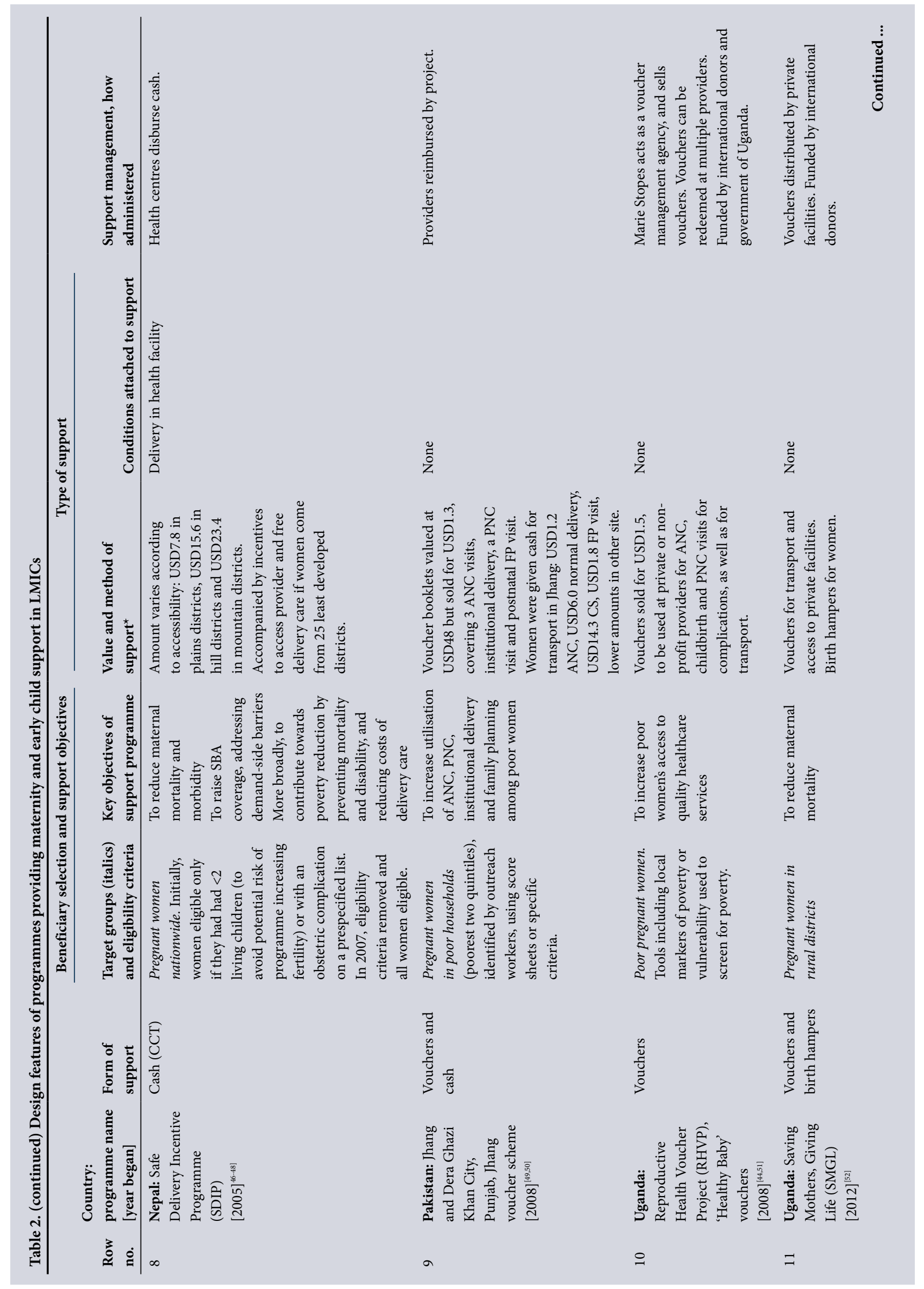




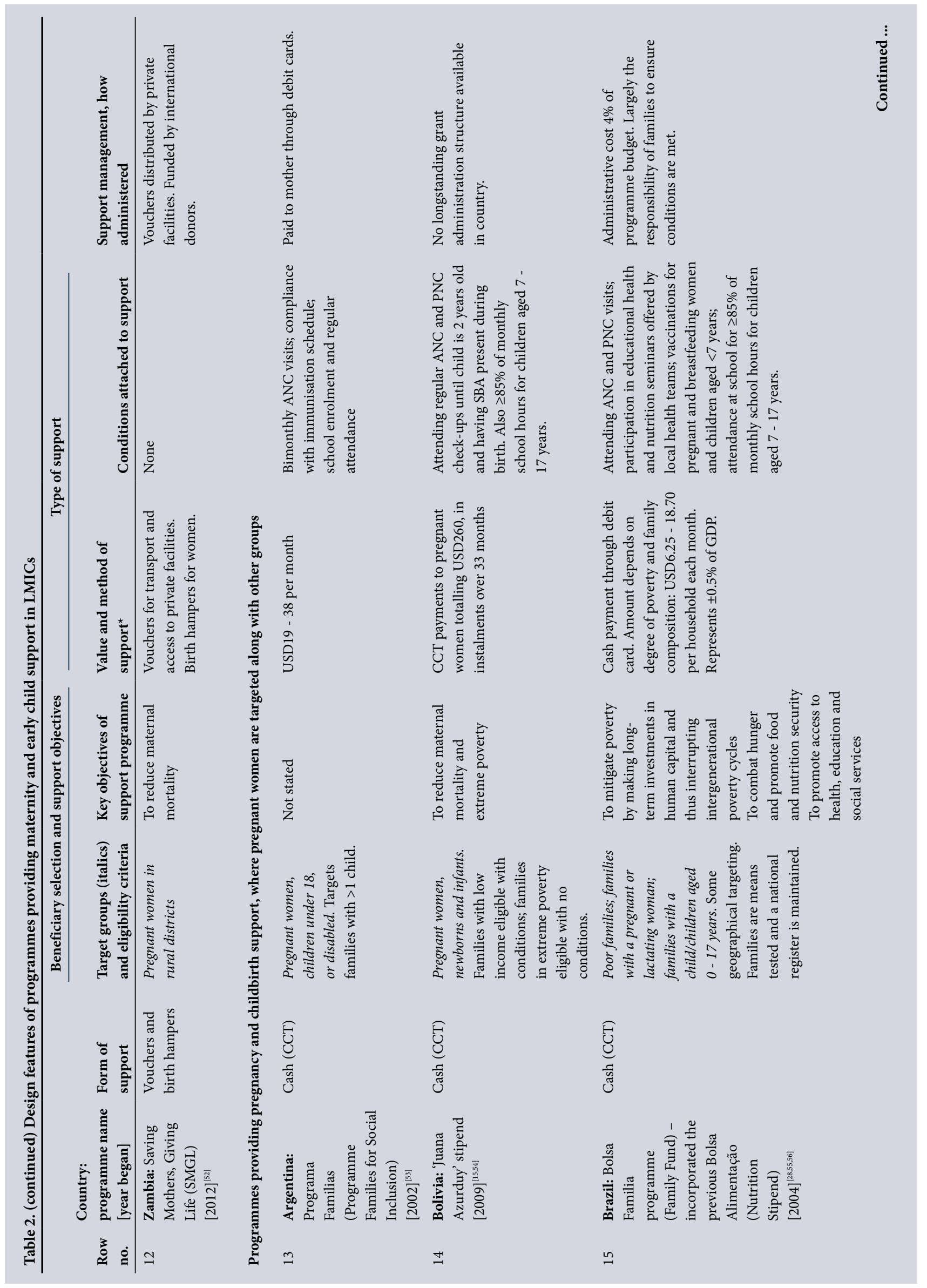




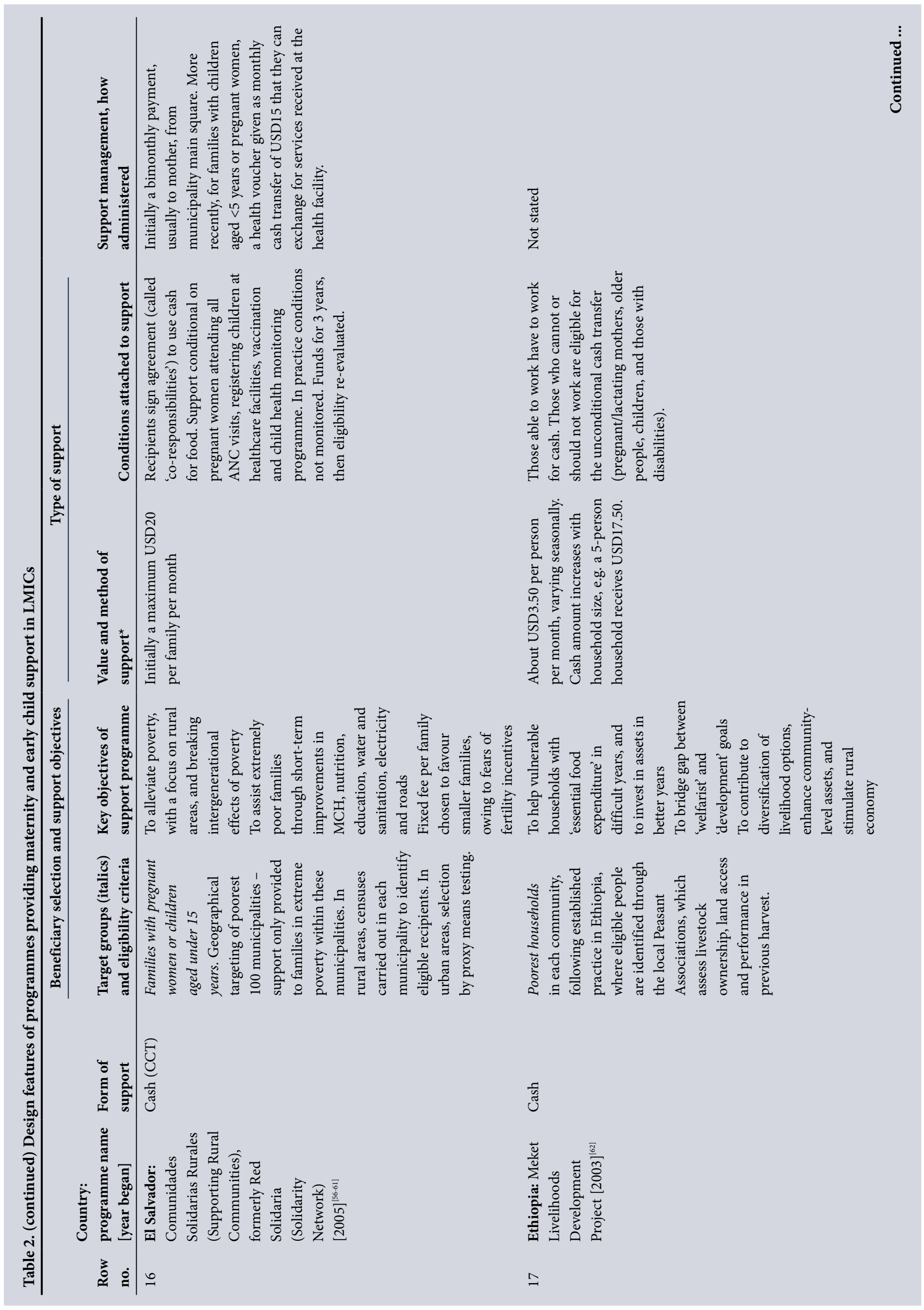




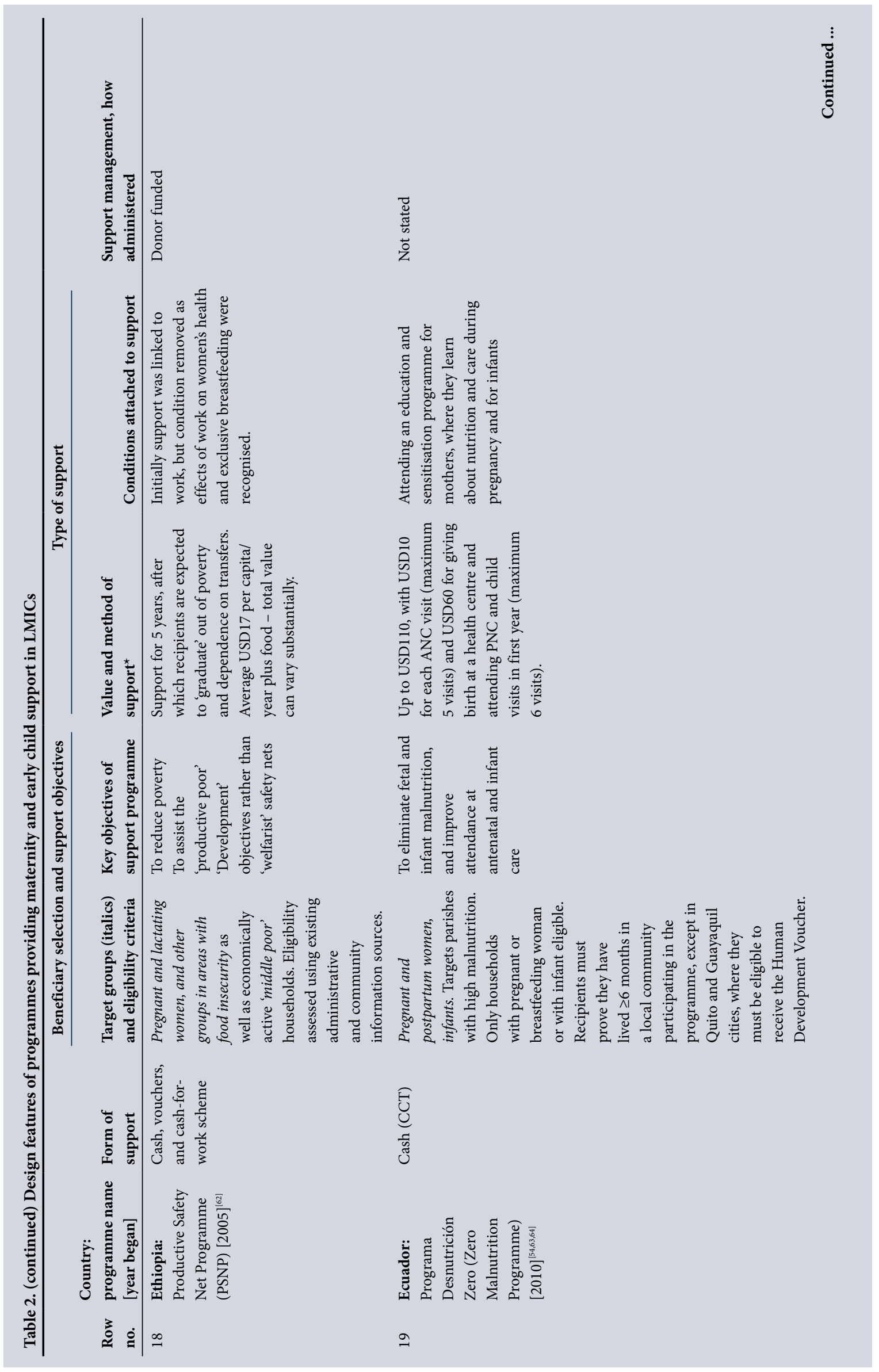




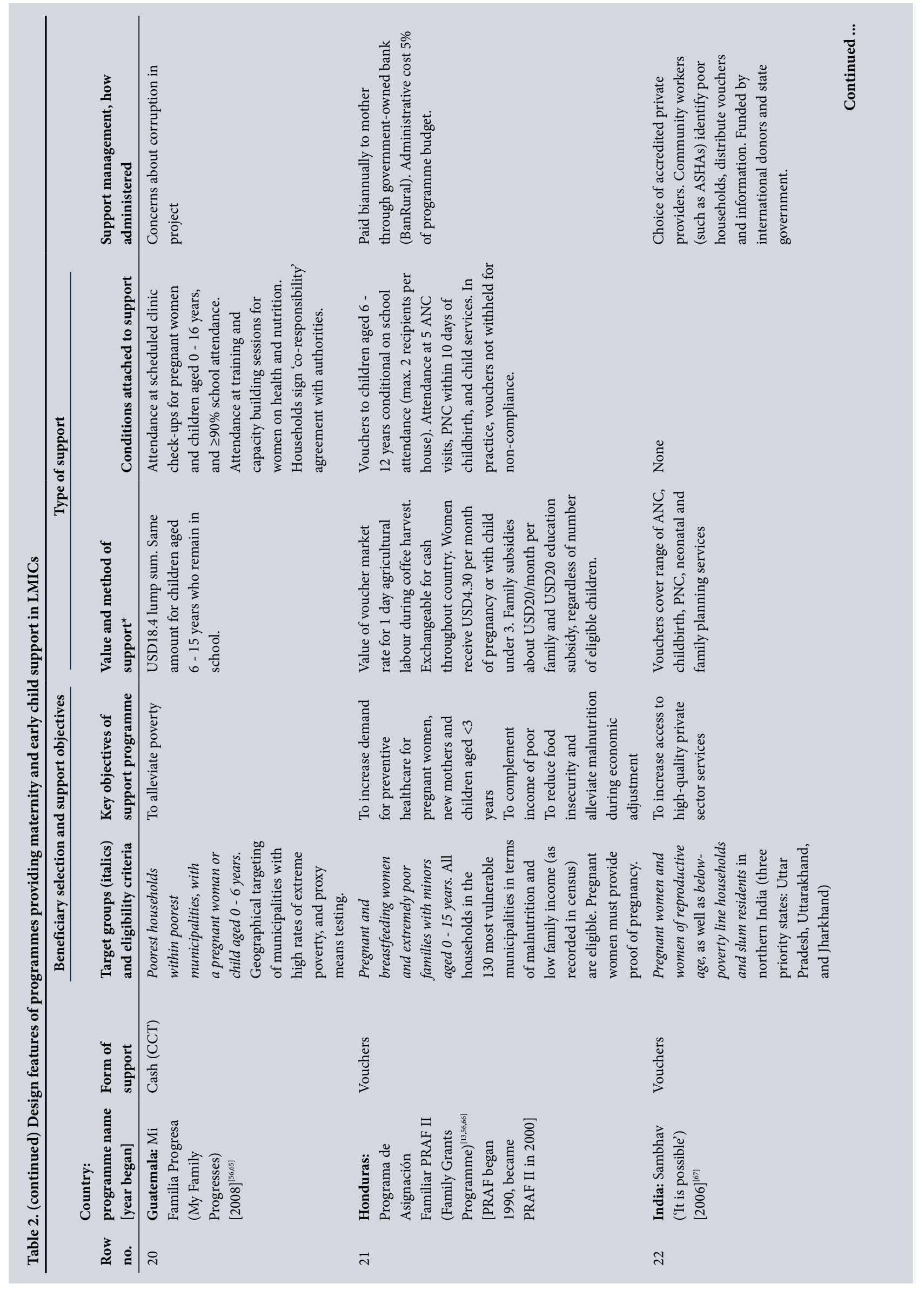




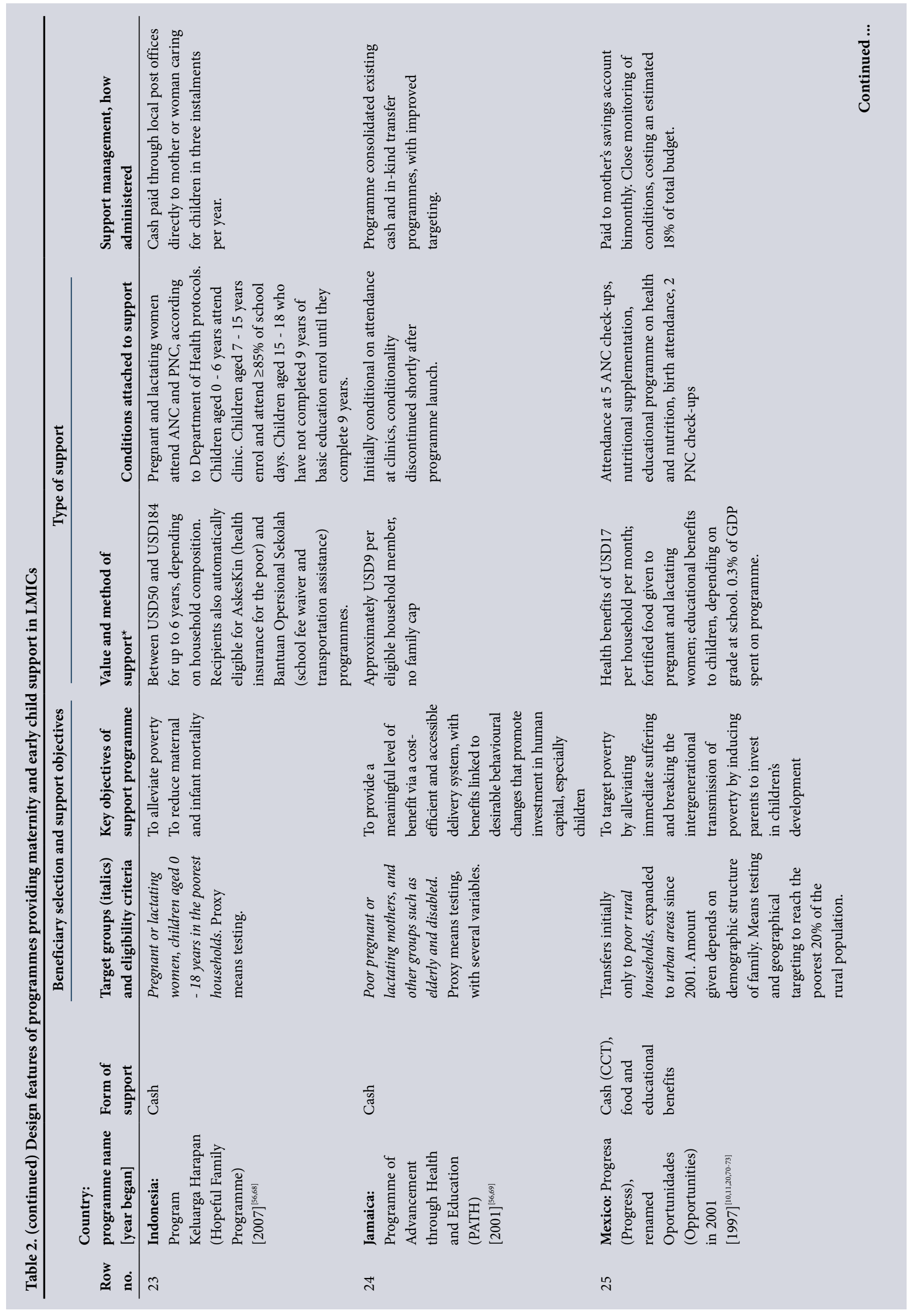




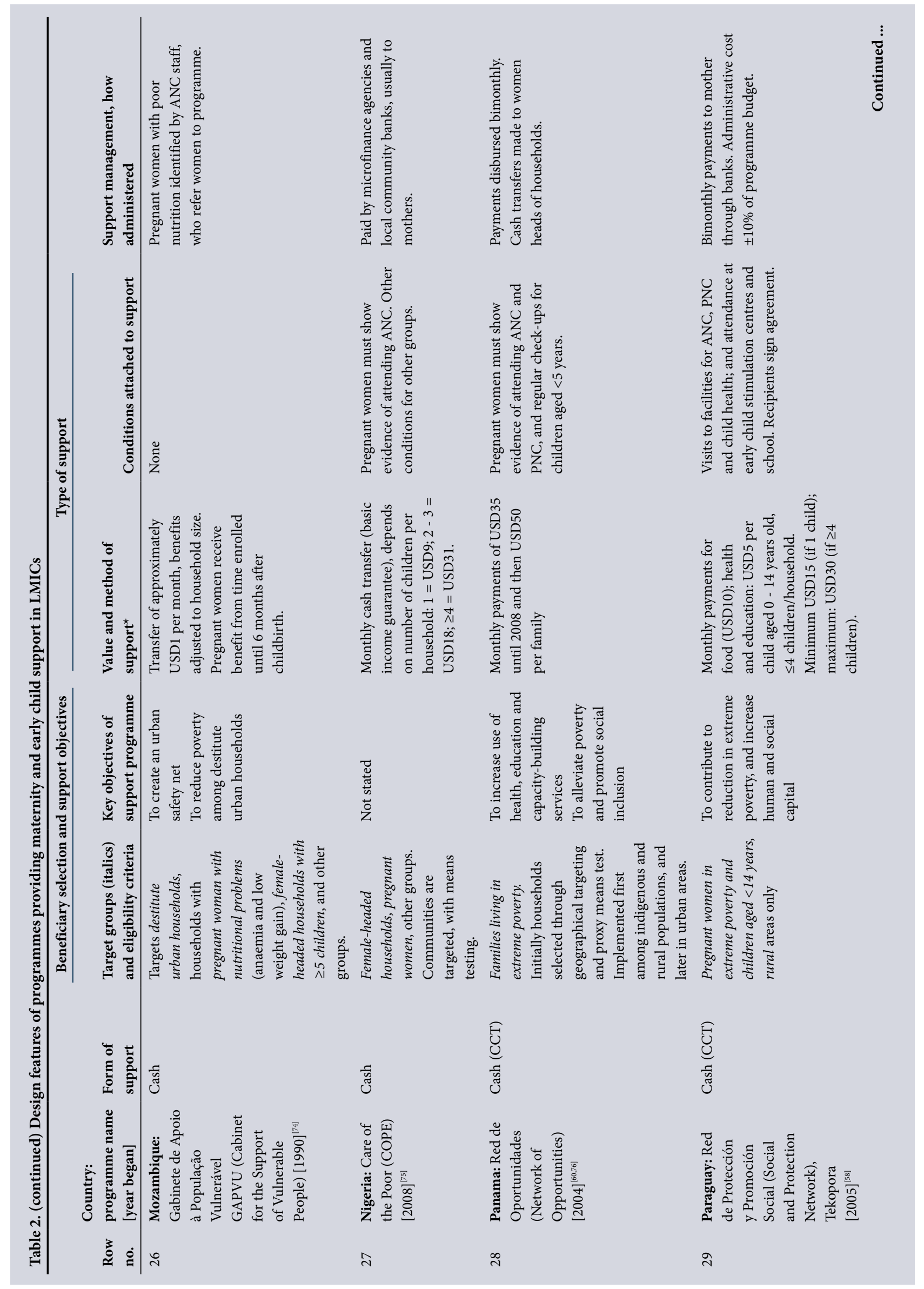




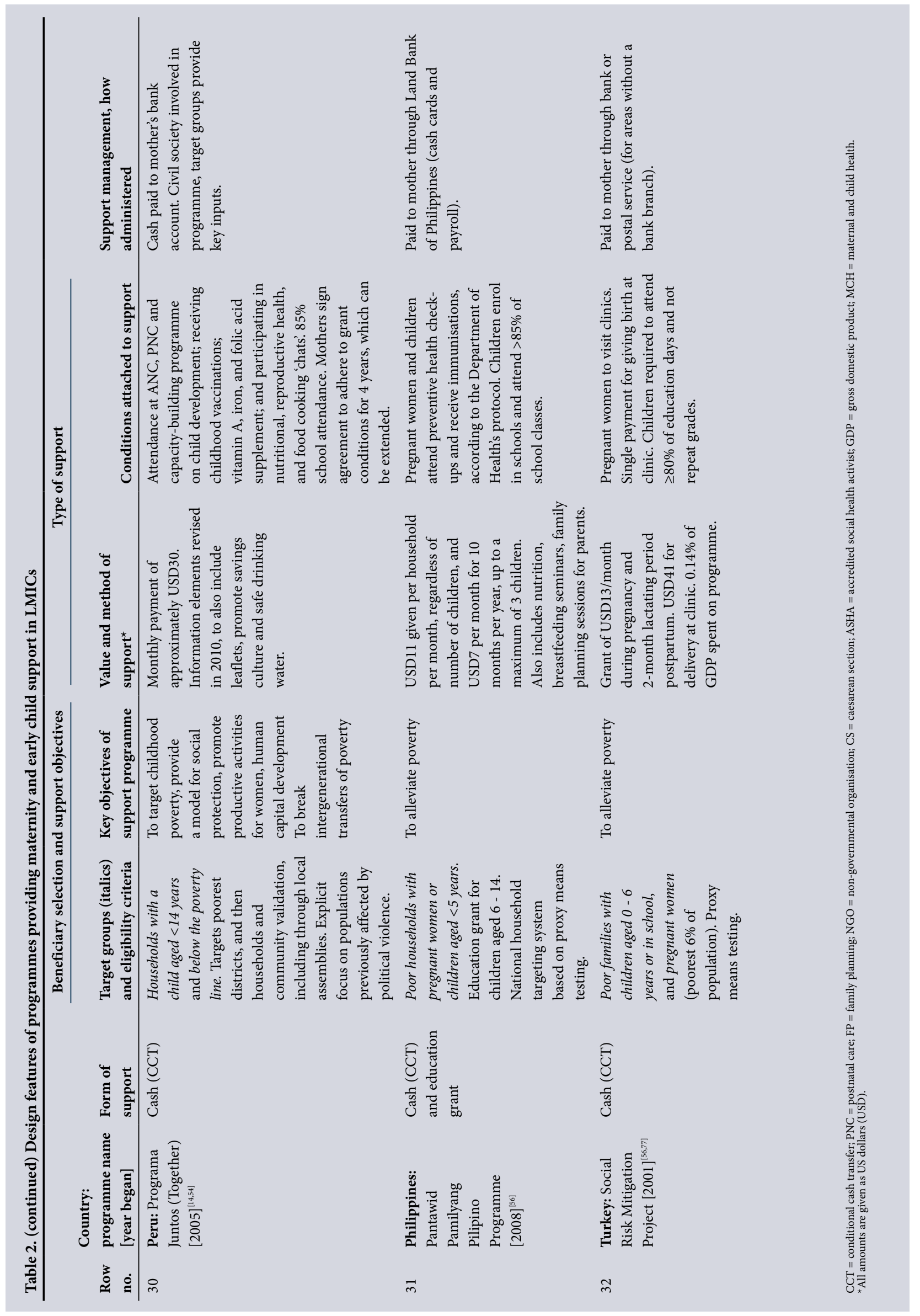


Three programmes that initially imposed such conditions later dropped them (Bangladesh, row 1; India, row 4; Nepal, row 8).

\begin{abstract}
Types of support
Six projects consisted of cash transfers only, with no conditions or explicit attempts to create linkages with health services. A further 14 of the 32 programmes also involved cash support only, but tied this to conditionalities around ANC attendance, having an SBA or postpartum care visits. The remaining 12 used means other than cash to promote linkages between support and service utilisation. A Cambodian scheme, for example, provided cash and vouchers for attending health services (row 2). Voucher coupons were used for visits to health facilities (including for private sector providers), institutional delivery and transport costs. Other strategies included providing gift hampers for women, nutritional supplementation and education, and cooking or counselling sessions at facilities in addition to cash or vouchers. In many projects, the inclusion of multiple types of support meant that parallel administrative systems were required. Grants in Latin America mainly adopted the conditional cash transfer approach, although in Bolivia (row 14) and a few other instances, families in extreme poverty also received nonconditional payments.
\end{abstract}

\section{Amount of support and payment mechanisms}

The value of cash transfers varied considerably, from relatively small amounts (e.g. USD1 per month in Mozambique, row 26) to USD260 paid to pregnant women in Bolivia, who receive instalments until the child is 2 years old (row 14). In some programmes the amounts given to pregnant women varied, with higher amounts provided in areas that were poorer, more remote, or had lower coverage of services (India, row 4; Brazil, row 15). In several instances, benefits given during pregnancy were a supplement to the support already provided by the state to poor families.

In cash-based programmes, payments were mainly made to debit or savings cards (Argentina, row 13; Brazil, row 15; Mexico, row 25; Peru, row 30; Philippines, row 31; Turkey, row 32). Money was also disbursed through health centres and postal services (Indonesia, row 23; Turkey, row 32), and even from the main square of municipalities (El Salvador, row 16). Cash was even home-delivered in one instance in India. Payments were usually made monthly, but some were bimonthly or even once off. One project gave a once-off payment to parents of twins (Mongolia, row 7).

\section{Practical experience with implementation}

Many of the smaller donor-funded projects encountered serious implementation issues, although these problems were also experienced by some of the larger ones. Communication with people eligible for support emerged as a problem in Nepal, for example, where a study showed that only $27 \%$ of the eligible population were aware of the grant (row 8). In contrast, in Uganda $90 \%$ of women were aware of the scheme, thanks to use of mass media such as radio (row 11). Finally, some reports of corruption were noted. This involved, for example, health workers taking money intended for pregnant women, and giving vouchers to ineligible women in programmes that paid commissions to staff for each voucher distributed (Kenya, row 6).

In many instances, programmes that used complex procedures for determining eligibility struggled to identify individuals requiring support, even ending up with the lowest uptake among the poorest women (India, row 4; Nepal, row 8). Some problems were also noted with cash disbursement processes; for example, women in Mozambique waited on average 7 hours at collection points, and payments were often delayed by several months (row 26). Women in Peru had high transport costs to reach a designated bank for grant collection (row 30).

Rigour in monitoring compliance with conditionalities varied markedly between projects. In some, there was little or no attempt to enforce conditions. For example, in El Salvador instalments were paid without confirming attendance at services, and recipients simply had to sign an agreement that they would use the money for food (row 16). Programmes with more rigorous measures to monitor conditionalities appeared to have higher administrative costs. Administrative costs ranged from $4-5 \%$ of the overall budget in areas with relatively lax controls (Brazil, row 15; Guatemala, row 20) to an estimated $18 \%$ in Mexico (row 25). High costs of monitoring conditionalities and other operational expenses in Nepal meant that only half the money in the programme was used for disbursements (row 8). Some programmes reported that they were able to resolve initial administrative constraints and gradually improve the scheme's performance (Bangladesh, row 1; Nepal, row 8 ). Not surprisingly, eligibility procedures and payment methods were often simplified over time (Bangladesh, row 1; India, rows 3 and 4), and several programmes dropped some or all conditionalities (India, row 4; Jamaica, row 24).

\section{Discussion}

This article summarises experiences in LMICs with the design and implementation of grants to support women during pregnancy. Overall, the evidence indicates that feasibility and efficiency were highest where programmes achieved economies of scale through integrating support for women and children within one system, and adopting simplified procedures, including uncomplicated enrolment and disbursement procedures, cash-only support, and few or no conditionalities (Table 3).

Aside from the absence of pregnancy support, the SA social support programmes closely resemble those in Latin American countries. Extending the existing CSG to begin in pregnancy would ensure further alignment with those projects, and move closer to attaining the benefits that women and children have gained there. A pregnancy support grant would also help align women in the formal sector with other women who are more at risk. While the formal sector has long acknowledged the need to alleviate the financial burdens of pregnancy through maternity leave benefits, women in the informal sector are generally excluded from such assistance, as are unemployed women.

Attendance at ANC and facilities for childbirth can be linked to pregnancy support at very low cost through, for example, requiring women to bring an ANC card when enrolling in support. Lack of ANC attendance remains a key cause of maternal deaths and of mother-to-child transmission (MTCT) of HIV in SA. ${ }^{[78]}$ ANC coverage is about $90 \%$, similar in all socioeconomic quartiles, but far fewer women in the poorest quartile attend ANC before 20 weeks ( $57 \%$ v. $89 \%$ in the highest quartile) or have an SBA (92\% v. $98 \%$ in the highest quartile). ${ }^{[2]}$

To obtain maximum benefit, pregnant women would ideally initiate support as soon as pregnancy is diagnosed. Surprisingly, therefore, in the programmes reviewed, support was seldom configured to incentivise women to initiate support and attend ANC early in pregnancy. Earlier attendance would reduce risk of MTCT of HIV, as the earlier in pregnancy women initiate antiretrovirals, the lower the risk of transmission. ${ }^{[79]}$ It would also allow for the nutrition benefits described above. Beginning support in pregnancy would mean that the critical neonatal period would be covered, a major deficiency of the present CSG. Processing delays mean that currently support only begins several months, or even years, after birth. 
Table 3. Lessons for SA from the international experience with designing and operationalising pregnancy support

\begin{tabular}{ll}
\hline Characteristic & Lessons \\
\hline Objective of support & Aim to improve maternal and child health and to increase early ANC attendance and SBA
\end{tabular}
coverage, but also to make a major contribution to broader socioeconomic development goals. Frame support during pregnancy around improving infant and child health, which requires targeting the in utero and neonatal period, to overcome concerns about perverse incentives.

Scope of support Integrate support for pregnant women with that for children, aiming for a life-course approach, recognising that the health of the mother, fetus and child are inseparable.

Use a single grant administration system for both pregnant women and children, where grants for eligible pregnant women automatically become CSGs once the child is born.

Incorporating a national programme into existing CSG systems will lower transaction costs and result in other economies of scale.

Overall programme complexity

Use simple means of identifying the target group and provide cash-only support.

Have minimal or no conditionalities, aside from requiring women to bring an ANC card when enrolling in support.

Overcoming political and public concerns Concerns of policy makers and the public about the grant incentivising pregnancy may be alleviated by including design features to discourage such incentives, for example, by restricting support to women aged $>19$ years or to the first two pregnancies.

Such restrictions affect the most vulnerable groups and would reduce programme impact, but may be necessary to secure initial support for the programme.

As evidence accrues or advocacy from civil society grows, a decision could be made to remove such restrictions.

Type of support

Cash transfers are easier to administer than multifaceted support, which necessitates parallel administrative processes.

Use the large body of local and international evidence to reassure policy makers that women will spend grant money on food, transport to health facilities and preparation for the child.

Payment method

Value of support for pregnant women, relative to other groups

Identifying eligible groups Use existing national structures, such as those for CSG and pension pay-outs.

Use of monthly payments may reduce concerns of policy makers about misuse of funds. Pregnant women require higher levels of support than many other groups, including children. Doing so acknowledges the costs of pregnancy, and that pregnancy reduces women's ability to work, and recognises the contribution of women to society through pregnancy and childbearing.

Use simplified procedures, such as the existing CSG mechanisms.

Minimise delays in processing of applications so that support begins early in pregnancy. Targeting of geographical areas may be considered, especially in districts with low ANC or SBA coverage. These could be framed as a pilot, from which evidence is drawn on effectiveness and grant administration.

Timing of support Start support as early as possible in pregnancy, to optimise its impacts on birth weight and child development.

Early support would incentivise early ANC booking, and increase the duration of ARVs during pregnancy, important for PMTCT.

Having social support already available at childbirth ensures coverage of the critical neonatal and infant period (the CSG is often only commenced after infancy).

Ensuring compliance with conditionalities would be onerous for health staff and administration systems.

Simple means of incentivising service use could include requiring an ANC card as proof of pregnancy and proof of a facility delivery for conversion of a pregnancy grant into a CSG.

Communication strategy Use of media, such as the MomConnect mHealth platform and radio, could inform potential recipients of the grant, address public concerns, and mobilise broader social and political support.

Potential for corruption Attention is needed to what 'proof of pregnancy' is needed when applying for support. Use of ANC cards and perhaps a urine pregnancy test at the time of application may minimise corruption risks.

Use existing structures for CSG applications when transitioning pregnancy support to a CSG.

ARVs = antiretrovirals; PMTCT $=$ prevention of mother-to-child transmission of HIV.

Means testing, based on income, is currently used for determining eligibility for the CSG and pensions in SA, and could be applied similarly during pregnancy. Alternative approaches to means testing may include measurement of things such as type of housing or number of productive assets, which could provide a more multidimensional measurement of poverty. However, these approaches involve 
significant data collection and transaction costs. Doing away with means testing altogether and providing a universal grant for all women is one option, but this can become politically charged where poverty coincides closely with specific ethnic or political groupings. Similarly, strict implementation of conditions can end up penalising the most vulnerable, and would undermine the central purpose of the grant.

Further issues relating to eligibility include the need to legally verify pregnancy during enrolment in pregnancy support. Pregnancy confirmation could be ascertained through means such as a blood or urine pregnancy test from a certified laboratory, a urine pregnancy test done at the grant processing facility, and the use of antenatal clinic cards. A birth certificate could then be required to continue the grant after delivery.

Possible unintended consequences of maternity support In addition to ensuring that the programme is designed optimally, the benefits of maternity support need to be weighed against any potential negative consequences. Fears of the potential for maternity and early child support to encourage childbearing, especially among young women, often lead to political and social hesitation to implement pregnancy support. These concerns often reveal underlying gender and class prejudices, and may well account for the absence of pregnancy support in SA to date. Globally, the assertion that social welfare support creates a perverse incentive in the form of encouraging a higher incidence of pregnancy has been tested as far back as the 1970s, and found to be unsupported by research. ${ }^{[00,81]}$ Moreover, several large studies in SA have demonstrated that providing the CSG clearly does not induce perverse incentives for pregnancy ${ }^{[6,82,83]}$ Nevertheless, to assuage the concerns of policy makers, it may be worth framing support around improvements in newborn and child health, rather than women's benefits. Features that explicitly discourage fertility could be included in the initial design of pregnancy support, even though this may initially impact most on vulnerable groups. These features could then be abandoned over time, as has occurred in other programmes.

Politicians and the public may also be concerned that women might spend grant money on non-essential or luxury items. The studies reviewed and evidence of CSG spending, however, show clearly that women use grant money for food and other essential goods. In the Brazil and Mozambique programmes, $60-70 \%$ of the cash transfer was spent on food, with proportions reaching $80 \%$ among families with severe food insecurity. ${ }^{[28,74]}$ Grants raise both the volume and, even more importantly, the variety of food eaten. ${ }^{[20]}$ In India, where health services were not free, women spent the majority of their grant money on accessing services. ${ }^{[36]}$ No increase in spending on alcohol, tobacco or adult clothes was detected in El Salvador, but purchases of children's clothing and shoes rose. ${ }^{[57]}$ Having multifaceted support, such as vouchers and cash, was seen as requiring parallel administrative processes, and is hard to justify when clearly monies are spent on food and access to care.

\section{Limitations of this review}

There is substantial heterogeneity between the programmes identified, as study settings, interventions and evaluation methods differed markedly. This limits the ability to directly compare studies and to draw overall conclusions. Additional evaluations of maternity support may have been missed, as studies examining the impact of such support are published in a broad range of fora, making it difficult to systematically identify all available evidence. Finally, much of the evidence located was of poor quality, limiting the ability to draw definitive conclusions.

\section{Conclusion}

A mother's nutritional status during pregnancy is a key determinant of her baby's weight at birth, and thus of childhood survival and life chances, as well as having intergenerational effects. Yet grants to enhance maternal health and wellbeing during pregnancy are not currently provided in SA, and there is much uncertainty about how such a grant would be structured and implemented. Based on lessons learnt elsewhere, we conclude that a programme that provides cash only, has simplified enrolment procedures and is integrated within existing social grant systems would be feasible to implement.

Social assistance has short-term goals of relieving poverty, but also of accumulating human capital and thus reducing intergenerational effects of poverty, among other benefits. Pregnancy support is most uniquely able to achieve both goals, unlike emergency food relief, for example, which only addresses short-term imperatives. More generally, the overall benefits of cash transfers are established beyond doubt; the absence of pregnancy support in SA is a serious design flaw of the otherwise hugely successful CSG, and is long overdue. 2006 and 2011. 2014. http://beta2.statssa.gov.za/publications/Report-03-10-06/Report-03-1006March2014.pdf (accessed 1 November 2016).

2. Wabiri N, Chersich M, Shisana O, et al. Growing inequities in maternal health in South Africa: A comparison of serial national household surveys. BMC Pregnancy Childbirth 2016;16:256. http:// dx.doi.org/10.1186/s12884-016-1048-z

3. Scorgie F, Blaauw D, Dooms T, et al. 'I get hungry all the time': Experiences of poverty and pregnancy in an urban healthcare setting in South Africa. Global Health 2015;11:37. http://dx.doi.org/10.1186 s12992-015-0122-z

4. Victora CG, Adair L, Fall C, et al. Maternal and child undernutrition: Consequences for adult health and human capital. Lancet 2008;371(9609):340-357. http://dx.doi.org/10.1016/S0140-6736(07)61692-4 5. Martorell R, Zongrone A. Intergenerational influences on child growth and undernutrition. Paediat Perinat Epidemiol 2012;26(Suppl 1):302-314. http://dx.doi.org/10.1111/j.1365-3016.2012.01298.x

6. Department of Social Development, South African Social Security Agency, UNICEF. The South African Child Support Grant Impact Assessment: Evidence From a Survey of Children, Adolescent and Their Households. Pretoria: UNICEF South Africa, 2012.

7. Gueorguieva R, Morse SB, Roth J. Length of prenatal participation in WIC and risk of delivering a small for gestational age infant: Florida, 1996-2004. Matern Child Health J 2009;13(4):479-488. http:// dx.doi.org/10.1007/s10995-008-0391-8

8. Murray MF, Hunter BM, Bisht R, et al. Demand-side financing measures to increase maternal health service utilisation and improve health outcomes: A systematic review of evidence from low- and service utilisation and improve health outcomes: A systematic review of evidence from low- and
middle-income countries. JBI Libr Syst Rev 2012;10(58):4165-4567. http://dx.doi.org/10.15124/ middle-income

9. Aguero J, Carter M, Woolard I. The impact of unconditional cash transfers on nutrition: The South African Child Support Grant. Working Paper 39, Brasilia, International Poverty Centre. 2007. http:// www.ipc-undp.org/pub/IPCWorkingPaper39.pdf (accessed 1 November 2016).

10. Fernald LC, Gertler PJ, Neufeld LM. Role of cash in conditional cash transfer programmes for child health, growth, and development: An analysis of Mexico's Oportunidades. Lancet 2008;371(9615):828837. http://dx.doi.org/10.1016/S0140-6736(08)60382-7

11. Barber SL. Mexico's conditional cash transfer programme increases cesarean section rates among the rural poor. Eur J Public Health 2010;20(4):383-388. http://dx.doi.org/10.1093/eurpub/ckp184

12. Stecklov G, Winters P, Todd J, et al. Demographic externalities from poverty programs in developing countries: Experimental evidence from Latin America. American University, Washington DC, Department of Economics Working Paper Series. 2006. http://paa2006.princeton.edu/papers/60659 (accessed 1 November 2016).

13. Morris SS, Flores R, Olinto P, et al. Monetary incentives in primary health care and effects on use and coverage of preventive health care interventions in rural Honduras: Cluster randomised trial. Lancet 2004:364(9450):2030-2037. http://dx.doi.org/10.1016/S0140-6736(04)17515-6

14. Jones N, Vargas R, Villar E. Cash transfers to tackle childhood poverty and vulnerability: An analysis of Peru's Juntos programme. Environ Urban 2008;20(1):255-273. http://dx.doi. org/10.1177/0956247808089162

15. Moloney A. Difficulties hit Bolivia’s programme for pregnant women. Lancet 2010;375(9730):1955 http://dx.doi.org/10.1016/s0140-6736(10)60910-5

16. Ahmed S, Khan MM. Is demand-side financing equity enhancing? Lessons from a maternal health voucher scheme in Bangladesh. Soc Sci Med 2011;72(10):1704-1710. http://dx.doi.org/10.1016/j. socscimed.2011.03.031

17. Prado BH, Ávila MH. Evaluación externa de impacto del Programa Oportunidades. 2004. http://lanic utexas.edu/project/etext/oportunidades/2004/escobar.pdf (accessed 1 November 2016).

18. Hatt L, Nguyen H, Sloan N, et al. Economic evaluation of demand-side financing (DSF) for maternal health in Bangladesh. Abt Associates, 2010. http://reliefwebint/sites/reliefwebint/files/resources/ Bangladesh\%20DSF\%20evaluation_FINAL_Feb\%202010.pdf (accessed 1 November 2016).

19. Bhutta ZA, Yakoob MY, Lawn JE, et al. Stillbirths: What difference can we make and at what cost? Bhutta ZA, Yakoob MY, Lawn JE, et al. Stillbirths: What difference can we make a
Lancet 2011;377(9776):1523-1538. http://dx.doi.org/10.1016/S0140-6736(10)62269-6

20. Barber SL, Gertler P). The impact of Mexico's conditional cash transfer programme, Oportunidades, arber SL, Gertler P). The impact of Mexico's conditional cash transfer programme, Oportunidades,
on birthweight. Trop Med Int Health 2008;13(11):1405-1414. http://dx.doi.org/10.1111/j.1365on birthweight. Trop

21. Amarante V, Manacorda M, Miguel E, et al. Do cash transfers improve birth outcomes? Evidence from matched vital statistics, social security and program data. 2011. http://www.nber.org/papers/w17690 (accessed 1 November 2016).

22. Besharov DJ, Germanis P. Evaluating WIC. Eval Rev 2000;24(2):123-190. http://dx.doi org/10.1177/0193841 x0002400201

23. Bhutta ZA, Chopra M, Axelson H, et al. Countdown to 2015 decade report (2000-10): Taking stock of maternal, newborn, and child survival. Lancet 2010;375(9730):2032-2044. http://dx.doi.org/10.1016/ S0140-6736(10)60678-2

24. Rivera JA, Sotres-Alvarez D, Habicht JP, et al. Impact of the Mexican program for education, health, and nutrition (Progresa) on rates of growth and anemia in infants and young children: A randomized effectiveness study. JAMA 2004;291(21):2563-2570. http://dx.doi.org/10.1001/jama.291.21.2563 
25. Black MM, Cutts DB, Frank DA, et al. Special supplemental nutrition program for women, infants, and children participation and infants' growth and health: A multisite surveillance study. Pediatrics 2004;114(1):169-176. http://dx.doi.org/10.1542/peds.114.1.169

26. Lim SS, Dandona L, Hoisington JA, et al. India’s Janani Suraksha Yojana, a conditional cash transfe programme to increase births in health facilities: An impact evaluation. Lancet 2010;375(9730):20092023. http://dx.doi.org/10.1016/s0140-6736(10)60744-1

27. Black RE, Allen LH, Bhutta ZA, et al. Maternal and child undernutrition: Global and regional exposures and health consequences. Lancet 2008;371(9608):243-260. http://dx.doi.org/10.1016/S01406736(07)61690-0

28. Santos LMP, Paes-Sousa R, Miazagi E, et al. The Brazilian experience with conditional cash transfers: A successful way to reduce inequity and to improve health. Presented at the World Conference on Socia Determinants of Health, Brazil, 19-21 October 2011. http://www.who.int/sdhconference/resources/ draft_background_paper1_brazil.pdf (accessed 1 November 2016).

29. Hoddinott J. Early childhood nutrition increases adult wages. Eurochoices 2009;8(2):34-37. http:/ dx.doi.org/10.1111/j.1746-692x.2009.00130.x

30. Schmidt JO, Ensor T, Hossain A, et al. Vouchers as demand side financing instruments for health care A review of the Bangladesh maternal voucher scheme. Health Policy 2010;96(2):98-107. http://dx.doi. A review of the Bangladesh matern
$\mathrm{org} / 10.1016 / \mathrm{j}$.healthpol.2010.01.008

31. Nguyen HT, Hatt L, Islam M, et al. Encouraging maternal health service utilization: An evaluation of the Bangladesh voucher program. Soc Sci Med 2012;74(7):989-996. http://dx.doi.org/10.1016/j. socscimed.2011.11.030

32. Ahmed S, Khan MM. A maternal health voucher scheme: What have we learned from the demandside financing scheme in Bangladesh? Health Policy Plan 2011;26(1):25-32. http://dx.doi.org/10.1093/ heapol/czq015

33. Ir P, Horemans $\mathrm{D}$, Souk $\mathrm{N}$, et al. Using targeted vouchers and health equity funds to improve access to skilled birth attendants for poor women: A case study in three rural health districts in Cambodia. BMC Pregnancy Childbirth 2010;10:1. http://dx.doi.org/10.1186/1471-2393-10-1

34. Por I, Horeman D, Narin S, van Damme W. Improving access to safe delivery for poor pregnant women: A case study of vouchers plus health equity funds in three health districts in Cambodia. Stud Health Serv Org Policy 2008:24:225-255.

35. Bellows NM, Bellows BW, Warren C. Systematic Review: The use of vouchers for reproductive health services in developing countries. Trop Med Int Health 2011:16(1):84-96. http://dx doiorg/10.1111/ j.1365-3156.2010.02667 $x$

36. DMMAS study team. Executive summary of DMMAS study. 2010. http://phrsindia.org/wp-content/ uploads/2015/09/AdvocacyExSummDMMAS.pdf (accessed 1 November 2016).

37. Mandal DK, Kaur P, Murhekar MV. Low coverage of Janani Suraksha Yojana among mothers in 24-Parganas (South) of West Bengal in 2009. BMC Proc 2012;6(Suppl 1):O3. http://dx.doi org/10.1186/1753-6561-6-S1-O3

38. Lahariya C. Cash incentives for institutional delivery: Linking with antenatal and post natal care may ensure 'continuum of care' in India. Indian J Community Med 2009;34(1):15-18. http://dx.doi. org $/ 10.4103 / 0970-0218.45370$

39. Bredenkamp C. Results-based financing for Health (RBF): India: The Janani Suraksha Yojana (JSY) program. World Bank, 2009. https://www.rbfhealth.org/sites/rbf/files/RBF_Country_INDIA_R1.pd (accessed 3 November 2016).

40. Government of India, Ministry of Women and Child Development. Approval of Indira Gandhi Matritva Sahyog Yojana (IGMSY) - Conditional Maternity Benefit Scheme. 2010. http://wcd.nic.in/ sites/default/files/IGMSYscheme.pdf (accessed 1 November 2016).

41. Bellows B, Kyobutungi C, Mutua MK, et al. Increase in facility-based deliveries associated with a maternal health voucher programme in informal settlements in Nairobi, Kenya. Health Policy Plan 2013;28(2):134-142. http://dx.doi.org/10.1093/heapol/czs030

42. Abuya T, Njuki R, Warren CE, et al. A policy analysis of the implementation of a Reproductive Health Abuya T, Njuki R, Warren CE, et al. A policy analysis of the implementation of a Reproductive Health
Vouchers Program in Kenya. BMC Public Health 2012:12:540. http://dx.doi.org/10.1186/1471-2458-12-540

43. Obare F, Warren C, Njuki R, et al. Community-level impact of the reproductive health vouchers programme on service utilization in Kenya. Health Policy Plan 2013;28(2):165-175. http://dx.doi org/10.1093/heapol/czs033

44. Aneesa A, Gitonga N, O’Hanlon B, et al. Insights from innovations: Lessons from designing and implementing family planning/reproductive health voucher programs in Kenya and Uganda. Private Sector Partnerships-One project, Abt Associates Inc., 2009. http://pdf.usaid.gov/pdf_docs/Pnadp185. pdf (accessed 1 November 2016).

45. Humphreys BR, Sauer R. Special Issue: Sport and public policy. In: Humphreys BR, Sauer R, eds. Contemporary Economic Policy. Oxford, UK: Blackwell Publishing, 2007:483-648.

46. Powell-Jackson T, Morrison J, Tiwari S, et al. The experiences of districts in implementing a national incentive programme to promote safe delivery in Nepal. BMC Health Serv Res 2009;9:97. http://dx.doi. incentive programme to pro
org $10.1186 / 1472-6963-9-97$

17. Powell-Jackson T, Dev Neupane B, Tiwari S, et al. Evaluation of the Safe Delivery Incentive Programme: Final report of the evaluation. Support to the Safe Motherhood Programme, Nepal, 2008 Programme: Final report of the evaluation. Support to the Safe Motherhood Programme, Nepal, 2008 .
http://s3.amazonaws.com/zanran_storage/www.safemotherhood.org.np/ContentPages/2469459188.pdf http://s3.amazonaws.com/zan

48. Powell-Jackson T, Hanson K. Financial incentives for maternal health: Impact of a national programme in Nepal. J Health Econ 2012;31(1):271-284. http://dx.doi.org/10.1016/j.jhealeco.2011.10.010

9. Agha S. Changes in the proportion of facility-based deliveries and related maternal health service among the poor in rural Jhang, Pakistan: Results from a demand-side financing intervention. Int Equity Health 2011;10:57. http://dx.doi.org/10.1186/1475-9276-10-57

50. Agha S. Impact of a maternal health voucher scheme on institutional delivery among low income women in Pakistan. Reprod Health 2011;8:10. http://dx.doi.org/10.1186/1742-4755-8-10

51. Arur A, Gitonga N, O'Hanlon B, et al. Insights from innovations: Lessons from designing and implementing family planning/reproductive health voucher programs in Kenya and Uganda. Ab Associates Inc., 2009. http://pdf.usaid.gov/pdf_docs/Pnadp185.pdf (accessed 1 November 2016).

52. Kruk ME, Galea S. External Evaluation of Saving Mothers, Giving Life: Final report. 2013. http:// savingmothersgivinglife.org/docs/SMGL-Columbia-final-report-Oct-2013.pdf (accessed 1 November 2016).

53. World Bank. CCT Program Profile - Argentina. 2012. http://web.worldbank.org/WBSITE/EXTERNAL/ World Bank. CCT Program Profile - Argentina. 2012. http://web.worldbank.org/WBSITE/EXTERNAL/ 32 pagePK:148956 piPK:216618 theSitePK:282761 isCURL:Y,00.html (accessed 1 November 2016). 42 Molyneux M, Thomson M. Cash transfers, gender equity and womens empowerment in Peru, Ecuador 54. Molyneux M, Thomson M. Cash transfers, gender equity and women's empowerment in Peru,
and Bolivia. Gend Dev 2011;19(2):195-212. http://dx.doi.org/10.1080/13552074.2011.592631

55. Paes-Sousa R, Santos LM, Miazaki ES. Effects of a conditional cash transfer programme on child nutrition in Brazil. Bull World Health Organ 2011;89(7):496-503. http://dx.doi.org/10.2471/ BLT.10.084202
56. Fiszbein A, Schady N. Conditional Cash Transfers: Reducing Present and Future Poverty. Policy Research Report, World Bank. 2009. http://siteresources.worldbank.org/INTCCT/ Resources/5757608-1234228266004/PRR-CCT_web_noembargo.pdf (accessed 1 November 2016).

57. Henderson M. Análisis de los efectos e impactos del programa Comunidades Solidarias Rurales, Periodo 2005-2010. San Salvador, El Salvador, 2011.

58. Soares FV, Britto T. Confronting capacity constraints on conditional cash tansfers in Latin America: The cases of El Salvador and Paraguay. International Poverty Centre, 2007. http://www.ipc-undp.org/ pub/IPCWorkingPaper38.pdf (accessed 1 November 2016).

59. De Britto TF. The challenges of El Salvadors's conditional cash transfer programme, Red Solidaria. International Poverty Centre country study, 2007. http://www.ipc-undp.org/pub/IPCCountryStudy9. pdf (accessed 1 November 2016).

60. Cecchini S, Madariaga A. Programas de Transferencias Condicionadas: Balance de la Experiencia Reciente en América Latina y El Caribe. Cuadernos del CEPAL 95. 2011. http://www.cepal.org/es/ publicaciones/27854-programas-transferencias-condicionadas-balance-la-experiencia-reciente-america (accessed 1 November 2016).

61. Handa S, Davis B. The experience of conditional cash transfers in Latin America and the Caribbean. Development Policy Review, 2006. http://www.fao.org/3/a-ag429t.pdf (accessed 1 November 2016).

62. Save the Children UK, Yablonski I, O'Donnell M. Lasting benefits: The role of cash transfers in tackling child mortality. 2009. http://www.savethechildren.org.uk/sites/default/files/docs/Lasting_Benefit__low_ res_comp_revd_1.pdf (accessed 1 November 2016).

63. Samaniego P, Tejerina L. Financial inclusion through the Bono de Desarrollo Humano in Ecuador. Inter-American Development Bank. Technical Notes 206. 2010. https://publications.iadb.org/ bitstream/handle/11319/2365/Financial\%20Inclusion\%20Through\%20the\%20Bono\%20de $\% 20$ Desarrollo\%20Humano\%20in\%20Ecuador:\%20Exploring $\% 20$ options $\% 20$ and $\% 20$ beneficiary $\% 20$ eadiness.pdf? sequence=1 (accessed 1 November 2016)

64. MSP. Ministerio de Salud Pública del Ecuador. Proyecto Desnutrición Cero. 2012. http://www.salud. gob.ec/proyecto-desnutricion-cero-completa-cobertura-en-chimborazo/ (accessed 1 November 2016).

65. Gammage S, International Labour Organization. Conditional cash transfers and time poverty: An example from Guatemala. 2011. http://www.cepal.org/mujer/noticias/noticias/1/43711/GAMMAGE Conditiona_Cash_Transfers_and_Time-Poverty_03102011.pdf (accessed 1 November 2016).

66. Pan American Health Organization. Social protection in health schemes for mother, newborn and child populations: Lessons learned from the Latin American Region. 2008. http://new.paho.org/hq/ dmdocuments/2010/Social_Protection_Health_Schemes_MNCP.pdf (accessed 1 November 2016).

67. IFPS Technical Assistance Project. Sambhav: Vouchers make high-quality reproductive health services possible for India’s poor. Gurgaon, Haryana: Futures Group, ITAP, 2012. http://pdf.usaid.gov/pdf_docs/ possible for India’s poor. Gurgaon, Haryana:

68. Febriany V, Toyamah N, Sodo J, et al. Qualitative impact study for PNPM Generasi and PKH on the provision and the utilization of the Maternal and Child Health Services and Basic Education Services in the provinces of West Java and East Nusa Tenggara. Jakarta, Indonesia. 2011. http://www.smeru. or.id/sites/default/files/publication/pnpmgenerasi_eng.pdf (accessed 1 November 2016).

69. Levy D, Ohls J. Evaluation of Jamaica's PATH Conditional Cash Transfer Programme. J Dev Eff 2010;2(4):421-441. http://dx.doi.org/10.1080/19439342.2010.519783

70. Sosa-Rubi SG, Walker D, Servan E, et al. Learning effect of a conditional cash transfer programme on poor rural women's selection of delivery care in Mexico. Health Policy Plan 2011;26(6):496-507. http:// dx.doi.org/10.1093/heapol/czq085

71. Barber SL, Gertler PJ. Empowering women to obtain high quality care: Evidence from an evaluation of Mexico's conditional cash transfer programme. Health Policy Plan 2009;24(1):18-25. http://dx.doi. $\mathrm{org} / 10.1093 / \mathrm{heapol} / \mathrm{czn} 039$

72. Barham T Providing a Healthier Start to Life: The Impact of Conditional Cash Transfers on Neonatal and Infant Mortality. Boulder, Colo.: Department of Economics and Institute of Behavioral Science, University of Colorado, 2006. www.stanford.edu/group/SITE/archive/SITE_2006/Web\%20 Session\%202/Barham.pdf (accessed 1 November 2016).

73. Caldes N, Coady D, Maluccio J. The Cost of Poverty Alleviation Transfer Programmes: A Comparative Analysis of Three Programmes in Latin America. FCND Discussion Paper 174. Washington, DC: International Food Policy Research Institute, 2004. http://www.eldis.org/vile/upload/1/ document/0708/DOC22752.pdf (accessed 1 November 2016).

74. Datt G, Payongayong E, Garrett JL, et al. The GAPVU cash transfer program in Mozambique: An assessment. Food Consumption and Nutrition Division, International Food Policy Research Institute, 1997. http://citeseerx.ist.psu.edu/viewdoc/download?doi=10.1.1.58.5525\&rep=rep1\&type=pdf $\quad$ (accessed 1 November 2016)

75. World Bank. CCT Program Profile - Nigeria. 2012. http://web.worldbank.org/WBSITE/EXTERNAL/ TOPICS/EXTSOCIALPROTECTION/EXTSAFETYNETSANDTRANSFERS/0, ,ontentMDK:220636 21 pagePK:148956 piPK:216618 theSitePK:282761 isCURL:Y,00.html (accessed 1 November 2016).

6. MIDES. Ministerio de Desarrollo Social. Red de Oportunidades. Informe del Equipo Técnico. 2007. http://www.mides.gob.pa/?page_id=555 (accessed 1 November 2016).

77. Adato $\mathrm{M}$, Roopnaraine $\mathrm{T}$, Becker $\mathrm{E}$. Understanding use of health services in conditional cash transfer programs: Insights from qualitative research in Latin America and Turkey. Soc Sci Med 2011;72(12):1921-1929. http://dx.doi.org/10.1016/j.socscimed.2010.09.032

78. National Department of Health, South Africa. Saving Mothers 2011-2013: Sixth report on the Confidential Enquiries into Maternal Deaths in South Africa. 2015. http://www.kznhealth.gov.za/ $\mathrm{mcwh} /$ Maternal/Saving-Mothers-2011-2013-short-report.pdf (accessed 1 November 2016).

79. Van der Merwe K, Chersich MF, Technau K, et al. Integration of antiretroviral treatment within antenatal care in Gauteng Province, South Africa. J Acquir Immune Defic Syndr 2006;43(5):577-581. http://dx.doi.org/10.1097/01.qai.0000243099.72770.d2

80. Presser HB, Salsberg LS. Public assistance and early family formation: Is there a pronatalist effect? Soc Probl 1975;23(2):226-241. http://dx.doi.org/10.2307/799658

81. Moore KA, Caldwell SB. The effect of government policies on out-of-wedlock sex and pregnancy. Fam Plann Perspect 1977;9(4):164-169. http://dx.doi.org/10.2307/2134493

82. Makiwane M. The Child Support Grant and teenage childbearing in South Africa. Dev South Afr 2010;27(2):193-204. http://dx.doi.org/10.1080/03768351003740498

83. Makiwane M, Udjo E. Is the Child Support Grant Associated With an Increase in Teenage Fertility Makiwane M, Udjo E. Is the Child Support Grant Associated With an Increase in Teenage Fertility
in South Africa? Evidence from National Surveys and Administrative Data. Pretoria: Child, Youth, Family and Social Development, Human Sciences Research Council, 2006.

Accepted 19 September 2016 


\section{Appendix 1. Search strategy}

1. Medline (PubMed) $9 / 7 / 12$ (540 results)

(maternal[TI/AB] OR mothers[MeSH] OR pregnanc ${ }^{\star}[\mathrm{TI} / \mathrm{AB}]$ OR pregnanc $\left.^{*}[\mathrm{MeSH}]\right)$ AND (grant ${ }^{*}[\mathrm{TI} / \mathrm{AB}]$ OR welfare[TI/AB] OR benefit[TI/AB])

2. Academic search complete (EBSCO Host) 10/7/12 (53 results) ((DE "MOTHER \& child") OR (DE "PREGNANCY")) AND ((DE "MATERNAL \& infant welfare") OR (DE "PUBLIC welfare policy"))

3. Educational Resources Information Centre (ERIC) 10/7/12 (20 results)

(DE "Pregnancy" OR DE "Mothers") AND (DE “Grants")

4. Psychology and Behavioural Sciences Collection 10/7/12 (5 results)

(DE "PREGNANCY" AND (DE "GRANTS (Money)" OR DE "MATERNAL \& infant welfare" OR DE "PUBLIC welfare")

5. Global Health Library $17 / 7 / 12$

Search 1 ( 49 results)
S1: ((((DE "pregnancy") OR (DE “mothers")) OR (DE "maternity services")) OR (DE “maternal nutrition")) OR (DE "child nutrition")

AND

S2: (((DE "grants") OR (DE "child welfare" OR DE "nutrition policy" OR DE "program participants" OR DE "social policy" OR DE "social services")) OR (DE “incentives")) AND (S1 and S2)

Search 2 (26 results)

S1 ((DE "grants") OR (DE “incentives")) OR (DE "social welfare") AND

S2 ((DE "grants") OR (DE “incentives")) OR (DE "social welfare") Search (32 results)

S1 ((((DE "maternity services" OR DE "health services") AND (DE "food distribution programs" OR DE "development policy" OR DE "emergency relief" OR DE "food security")) OR (DE "Food Stamp Program")) OR (DE "nutrition programmes")) OR (DE "government policy")) OR (DE "social welfare") AND

S2: (((DE "pregnancy") OR (DE "children")) OR (DE “mothers")) AND (DE "low income groups") 